\title{
Growth, Poverty Reduction, and Inequality in Rwanda
}

Andy McKay and Marijke Verpoorten

\subsection{Country Context and Economic Performance}

Rwanda has many features which make it unique and of interest to analysts. It has the highest population density in Africa. Even more than many subSaharan African countries, it is very highly dependent on agriculture, but its originally fertile soils face a continued risk of environmental degradation, and average farm size is rapidly falling (the average farm size is now only 0.7 ha, with much of this land not being easy to cultivate). Without doubt, the country needs to diversify out of agriculture, but finding these alternative activities has been and remains a major challenge.

Rwanda has also attracted international attention because of its disastrous period of violent conflict in the early to mid-1990s. ${ }^{1}$ Also well known, though, is the impressive economic growth it has experienced since. Per capita GDP in local currency values since 1970 is presented in Figure 6.1. What this shows is consistent sustained growth from 1995 onwards, in sharp contrast to the stagnation of GDP in the 1980s and early 1990s. By 2006, GDP per capita had reached its highest level to date, and by 2012, it was about 50 per cent larger than GDP per capita prior to the armed conflicts of the 1990s. Growth seems to be even faster in recent years. All productive sectors have grown consistently over this period, agriculture and industry included, but according to national accounts data the fastest growth has been in the services sector, especially in wholesale and retail trade and transport, storage, and

\footnotetext{
${ }^{1}$ Poverty and land scarcity added to the intensity of the conflict (Verpoorten 2012), but the root causes lay elsewhere (Ingelaere and Verpoorten 2014).
} 


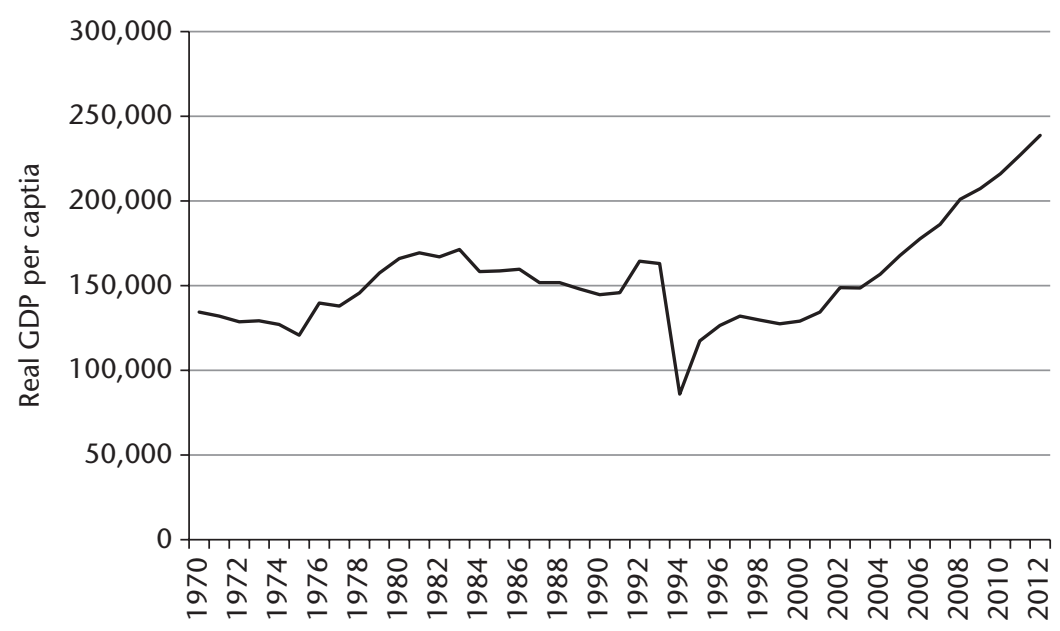

Figure 6.1. Evolution of real per capita GDP in Rwanda, constant local currency units Source: World Development Indicators (2014)

communications. In addition, there is evidence of significant improvements in living conditions over recent years.

Population growth was historically high in Rwanda, doubling between 1970 and 1990 (growing at an average of 3.3 per cent a year). Population growth has been slower in the post-war period at around 2.6 per cent per annum, but the momentum of past growth means that the population continues to increase at a fast rate, and in an increasingly land-scarce environment.

There are different views among analysts about the factors underlying Rwanda's recent economic success story. Important elements often discussed include post-war catch-up; massive aid inflows; increased budget shares for health, education, and agriculture; the fertility transition; and the rise in international commodity prices. Booth and Golooba-Mutebi (2012: 387) stress the aspect of governance, arguing that Rwanda is a developmental authoritarian state that actively promotes private-sector development and keeps the most detrimental forms of rent-seeking in check with 'a set of arrangements for managing economic rents in a centralized way and deploying them with a view to the long term'.

Even if aid and post-war catch-up may be important, it is impossible to deny the role of government policy in Rwanda. Numerous policy changes have been made, including among others the 1999 new inheritance law that grants equal rights to male and female children; the new constitution of 2003 that introduces gender quotas at all levels of decision-making; free and mandatory primary education; major changes in agricultural and land policy; the introduction of performance-based financing for health care centres in 2006 as well as performance contracts between each district and the central government 
(imihigo); an intense family planning campaign in 2007; and mandatory health insurance in 2008.

Many studies have looked at these policy changes to determine how they have contributed to the Rwandan success story. Guariso et al. (2012) discuss the transformation of the Rwandan coffee sector; Ayalew et al. (2011) study the impact of land tenure regularization on investment, maintenance of soil conservation measures, and women's land access; Basinga et al. (2010), Kalk (2008), and Kalk etal. (2010) study the impact of the introduction of performance-based financing in the health care sector; Nkurunziza et al. (2012) analyse the introduction of free primary education; Saksena et al. (2011) study the introduction of mutual health insurance; and Westoff (2012), Kabano et al. (2013), and Muhoza et al. (2013) look at the fertility transition.

Identifying causality remains, however, a challenge in these studies; and many policies still need to be properly evaluated. At the same time, some policies, for instance in relation to agricultural and land policy, have been criticized by many researchers, using mainly qualitative methods (Ansoms 2011; Huggins 2009; Newbury 2011).

The data, though, continues to indicate impressive growth performance. The focus of this chapter is to consider the distributional pattern of this growth and its impact on poverty. In section 6.2 we consider evidence on the evolution of many non-monetary indicators from the Demographic and Health Surveys for which several rounds have been conducted between 1992 and 2010. Section 6.3 focuses on consumption poverty and inequality, primarily based on surveys which have been conducted since 2000, though with a brief discussion of evidence dating back to 1990 as well as a brief first review of available qualitative evidence. Then in section 6.4 we draw on a small-scale panel dataset which enables an examination of mobility and consideration of other issues, while section 6.5 presents an extended discussion and synthesis while also discussing unresolved issues.

\subsection{The Evolution of Non-monetary Measures of Well-being}

As noted above, we first focus on trends in non-monetary indicators as revealed by the Demographic and Health Surveys (DHS), of which there were five rounds in 1992, 2000, 2005, 2007, and 2010. The first two surveys bracket a period of armed conflicts, namely the 1991-4 civil war, the 1994 genocide, and the 1994-8 refugee crisis and (counter-)insurgency operations. The more recent surveys were implemented in a period in which various government interventions took place in the health and education sector. The questionnaire design is broadly similar across the survey rounds, though 
the 2007 round was smaller and collected data on a more limited number of indicators. The first four surveys were designed to be representative at the level of the twelve provinces (in place before the 2006 administrative reform), while the latest survey is representative at the level of the thirty districts created during later administrative reform. The analysis here and in section 6.3 uses population weights, and focuses throughout on indicators which are comparable across the different survey rounds. Table 6.1 summarizes time trends in the average outcomes for a range of health, fertility, education, and housing indicators.

The infant mortality rate, as calculated from the five-year period preceding the survey, dropped dramatically from 109 in 2000 to 83 in 2005 to 50 in 2010. In contrast, in the period of armed conflict the same indicator had increased from 85 in 1992 to 109 in 2000 . Under-five mortality shows a similar trend and similar dramatic reduction from 2000. This falling mortality went hand in hand with improvements in child nutritional indicators, with stunting and wasting decreasing over the period 2005-10, and with reduced prevalence of diarrhoea and especially fever for under-fives in the two weeks preceding the survey. These improvements may in part reflect a better outreach of basic preventive health care measures. Vaccination coverage was always high but bed net ownership increased sharply and consistently from only 6.6 per cent of households in 2000 to 82.7 per cent in $2010 .^{2}$

Another big change over this period is the fall in the fertility rate between 2005 and 2010 from 6.1 to 4.6 respectively. From 1992 to 2005, the rate had not fallen and this is potentially a very important change. In line with this, the same 2005-10 period saw a marked increase in the use of contraceptives, and the unmet need for contraceptives declined considerably, from 37.9 per cent in 2005 to 20.8 per cent in 2010. Between 2005 and 2010, there were also sharp increases in delivery at a health facility (instead of at home), from below 30 per cent in and prior to 2005 to almost 80 per cent in 2010; and in the number of births assisted by trained medical staff. The maternal mortality ratio remains high in Rwanda, but shows a steady decline over the period 2000-10. It stood at 476 deaths per 100,000 live births in the 2010 DHS, down from 1,071 in 2000, again demonstrating impressive progress.

Education has been a major policy and donor focus, and both attendance and attainment have improved substantially over time. The share of men (aged 6 years or more) with no formal education fell from 29.4 per cent in 1992 to 24.9 per cent in 2000 to 19.4 per cent in 2005 and 13.0 per cent in 2010. The corresponding figures for women are 40.4 per cent, 32.6 per cent, 27.7 per cent, and 20.2 per cent. The mean years of education of the active

\footnotetext{
${ }^{2}$ The ownership of bed nets was not recorded in 1992.
} 


\section{Rapid Growth and Rapid Poverty Reduction}

Table 6.1. Selected non-monetary indicators for Rwanda

\begin{tabular}{|c|c|c|c|c|c|}
\hline DHS survey round & 1992 & 2000 & 2005 & $2007-8$ & 2010 \\
\hline \multicolumn{6}{|l|}{ Mortality rate } \\
\hline infant mortality & 85 & 109 & 83 & 64 & 50 \\
\hline under-five mortality & 151 & 196 & 152 & 103 & 76 \\
\hline \multicolumn{6}{|l|}{ Nutritional status } \\
\hline height-for-age (\% below $-2 \mathrm{sd}$ ) & 56.8 & 48.3 & 51.1 & n.a. & 44.2 \\
\hline weight-for-height (\% below - 2 sd) & 5.0 & 8.3 & 4.7 & n.a. & 2.8 \\
\hline weight-for-age (\% below $-2 \mathrm{sd}$ ) & 24.3 & 19.5 & 17.5 & n.a. & 11.4 \\
\hline \multicolumn{6}{|l|}{ Health condition past two weeks (age $0-5$ ) } \\
\hline diarrhoea (\%) & 22.0 & 17.2 & 14.4 & 13.9 & 13.3 \\
\hline fever $(\%)$ & 42.1 & 31.0 & 26.6 & 21.9 & 15.9 \\
\hline All vaccinations ( $\%$ children $12-23$ months) & 86.3 & 76.0 & 75.2 & 80.4 & 90.1 \\
\hline $\begin{array}{l}\text { Households owns mosquito net (any type, } \\
\% \text { ) }\end{array}$ & n.a. & 6.6 & 18.2 & 59.2 & 82.7 \\
\hline Total fertility rate ${ }^{a}$ & 6.2 & 5.8 & 6.1 & 5.5 & 4.6 \\
\hline \multicolumn{6}{|l|}{ Use of contraception ${ }^{b}$} \\
\hline any modern method (\%) & 12.9 & 5.7 & 10.3 & 27.4 & 45.1 \\
\hline unmet need for family planning (\%) & 38.9 & 35.6 & 37.9 & 100.0 & 20.8 \\
\hline Delivery at health care facility (\%) ${ }^{c}$ & 26.3 & 25.7 & 29.7 & 53.7 & 78.3 \\
\hline Assistance of trained personnel (\%) & 28.3 & 31.3 & 38.6 & 52.1 & 69.0 \\
\hline Maternal mortality rate ${ }^{\mathrm{d}}$ & n.a. & 1071 & 750 & n.a. & 476 \\
\hline \multicolumn{6}{|l|}{ Educational level } \\
\hline no education, men $(\%,>6$ year) & 29.4 & 24.9 & 19.4 & n.a. & 13.0 \\
\hline no education, women $(\%,>6$ year $)$ & 40.4 & 32.6 & 27.7 & n.a. & 20.2 \\
\hline mean years of education, men $15-65$ & 3.9 & 4.1 & 4.1 & n.a. & 4.6 \\
\hline mean years of education, women $15-65$ & 3.0 & 3.3 & 3.4 & n.a. & 4.0 \\
\hline \multicolumn{6}{|l|}{ Net attendance ratio ${ }^{\mathrm{e}}$} \\
\hline primary school, total & 61.5 & 72.0 & 80.6 & n.a. & 87.5 \\
\hline secondary school, total & 5.7 & 4.9 & 4.0 & n.a. & 14.4 \\
\hline \multicolumn{6}{|l|}{ Gross attendance ratio ${ }^{f}$} \\
\hline primary school, total & 84.6 & 104.5 & 134.2 & n.a. & 142.4 \\
\hline secondary school, total & 16.6 & 7.9 & 8.2 & n.a. & 26. \\
\hline \multicolumn{6}{|l|}{ Housing characteristics } \\
\hline has electricity (\%) & 2.3 & 6.2 & 4.8 & 6.0 & 9.7 \\
\hline finished floor (\%) & 11.0 & 13.1 & 13.0 & 14.6 & 16.9 \\
\hline \multicolumn{6}{|l|}{ Household durable goods } \\
\hline radio $(\%)$ & 32.3 & 35.2 & 45.8 & 58.2 & 62.6 \\
\hline television (\%) & n.a. & 2.4 & 2.3 & 3.4 & 5.3 \\
\hline bicycle (\%) & 6.4 & 7.6 & 11.0 & 12.2 & 15.2 \\
\hline motorcycle (\%) & 0.7 & 0.7 & 0.5 & 0.9 & 1.1 \\
\hline
\end{tabular}

Notes and source: Authors' calculations from DHS data, except for the fertility and mortality rates, under-five mortality rate, nutritional status, and health insurance which are taken from the DHS reports and gross attendance ratio which is taken from the DHS reports for 2000, 2005, and 2010, and from the WDI for 1992. ${ }^{a}$ For the three years preceding the survey and the percentage of women 15-49 currently pregnant. ${ }^{b}$ Among married women. ${ }^{\circ}$ Of live births in the last three years preceding the survey. ${ }^{\mathrm{d}} \mathrm{Per} 100,000$ live births, for the period of $0-4$ years prior to the survey. ${ }^{\mathrm{e}}$ The NAR for primary school is the percentage of the primary-school-age (7-12 years) population that is attending primary school. The NAR for secondary school is the percentage of the secondary-school-age (13-18 years) population that is attending secondary

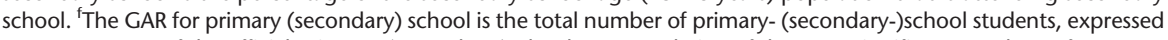
as a percentage of the official primary- (secondary-)school-age population. If there are significant numbers of over-age and under-age students at a given level of schooling, the GAR can exceed 100 per cent.

population (aged 15-65) increased from 3.9 in 1992 to 4.6 in 2010 for men, and from 3.0 in 1992 to 4.0 in 2010 for women.

The net attendance ratio (NAR) for primary school increased over the period 1991-2000 from 61.5 to 72.0, despite the violent conflicts, then increased 
further to 80.1 in 2005 and 87.5 in 2010. The NAR for secondary school is much lower and fell in the period of conflict (Guariso and Verpoorten 2013), but it then increased by more than ten percentage points during 2005-10. Gross attendance ratios (GAR) though are much higher, a result of slow grade progression during armed conflict (and so many over-age children). Gross attendance ratios for primary school increased greatly from 84.6 in 1992 to around 100 in 2000, close to 130 in 2005, and to approximately 140 in 2010. The GAR for secondary school decreased from 16.6 in 1992 to 7.9 in 2000, but then recovered to 8.2 in 2005 and further to 26.1 in 2010.

Finally the DHS surveys also collect data on housing characteristics and household assets. There were improvements over time in the two comparable housing indicators: electricity in the home and the construction material of the floor. This is especially apparent across the latest three rounds $(2005,2007$, 2010). Household ownership of durable goods also increased over time, with 62.6 per cent of households owning a radio in 2010, compared to 32.3 per cent in 1992. Likewise, bicycle ownership almost doubled over the period 1992-2010, from 6.4 per cent to 15.2 per cent, though ownership of a television or motorcycle remained low in 2010 despite small increases.

This analysis, though, focuses on average outcomes across the entire sample, where almost all indicators show improvements, often substantial improvements, over the period. But it is also important to look at heterogeneity: to what extent do poorer households share in these improvements? In the absence of income data, poverty is proxied on the basis of an asset index constructed using principal component analysis (Filmer and Pritchett 2001). ${ }^{3}$ Table 6.2 then looks at eight indicators across rich and poor, showing the ratio of the indicator for the top asset quintile to that of the lowest asset quintile. The disparity is smallest and most stable over time for primary school enrolment and vaccination coverage. For the other indicators, the general pattern is one of sharply increasing disparities during the period of armed conflict (1992-2000), followed in most cases by sharp reductions in disparities since 2000. The absolute levels of disparities are still large in some cases, notably for the secondary NAR, but in six out of the eight cases inequality in these outcomes fell, often sharply between 2000 and 2010; in the other two cases the disparity scarcely changed. The evidence suggests that poorer households shared in the improvements in these non-monetary indicators. A similar analysis comparing rural and urban areas shows the same pattern of disparity increasing during 1992-2000 and falling during 2000-10 (not reported).

\footnotetext{
${ }^{3}$ The resulting indices are given by Measure DHS for each round, and are constructed on the basis of a set of variables that vary across survey rounds. For instance, the 2005 and 2010 indices include information on mobile phone ownership, a variable that was only introduced in 2005. In addition, for some variables the answer categories varied between rounds, e.g. source of drinking water and type of toilet facilities.
} 
Table 6.2. The ratio of indicators between the richest 20 per cent and the poorest 20 per cent of the sample population

\begin{tabular}{|c|c|c|c|c|c|}
\hline DHS survey round & 1992 & 2000 & 2005 & $2007-8$ & 2010 \\
\hline Use of contraception ${ }^{a}$ & \multicolumn{5}{|c|}{$\begin{array}{l}\text { Ratio of indicator between top and bottom wealth } \\
\text { quintile }\end{array}$} \\
\hline any method (\%) & 1.45 & 3.26 & 2.88 & 1.79 & 1.32 \\
\hline any modern method (\%) & 1.53 & 6.19 & 3.72 & 1.78 & 1.29 \\
\hline Delivery at health care facility $(\%)^{\mathrm{b}}$ & 2.11 & 3.97 & 3.36 & 1.62 & 1.28 \\
\hline Assistance of trained personnel (\%) & 1.95 & 3.08 & 2.44 & 1.65 & 1.40 \\
\hline All vaccinations (\% children $12-23$ months) & 1.05 & 1.08 & 1.00 & 1.02 & 1.10 \\
\hline $\begin{array}{l}\text { Households owns mosquito net (any type, \%) } \\
\text { Net attendance ratio }{ }^{c}\end{array}$ & n.a. & 26.01 & 7.35 & 1.71 & 1.20 \\
\hline primary school, total & 1.39 & 1.18 & 1.10 & n.a. & 1.19 \\
\hline secondary school, total & 4.86 & 12.88 & 24.24 & n.a. & 4.74 \\
\hline
\end{tabular}

Notes and source: Authors' calculation from the DHS data. ${ }^{\mathrm{a} A m o n g}$ married women. ${ }^{\mathrm{b}}$ Of live births in the last three years preceding the survey. ${ }^{\circ}$ The NAR for primary school is the percentage of the primary-school-age (7-12 years) population that is attending primary school. The NAR for secondary school is the percentage of the secondary-school-age (13-18 years) population that is attending secondary school.

In sum, the overall pattern revealed by almost all of the DHS indicators is of big improvements in health, education, assets, and housing conditions between 2000 and 2010, and of improvements in which rural areas and the poor appear to share equally. In most cases this is in sharp contrast to the pattern in Rwanda over the years of conflict in the 1990s.

This raises the question of the causes of these improvements in nonmonetary outcomes. The period from 2000 onwards saw major policy initiatives and changes in relation to education and especially health. Compulsory and free primary education was introduced; large numbers of schools were constructed or refurnished in this period, and many who had missed school in the years of conflict attended later. As seen above, a very high rate of attendance was achieved. There were many initiatives in the health sector, including the introduction of performance-based financing and of compulsory health insurance; and all sectors were affected by the imihigo performance contracts described above. The intense family planning campaign and a big increase in contraceptive availability are likely to have contributed to the falling fertility rates. To decisively attribute the improved outcomes to these policies, more rigorous evaluations are needed.

\subsection{Trends in Consumption Poverty and Inequality}

The available data to assess consumption poverty primarily concern the postconflict period. Three comparable household surveys are available since 2000 and these are the main focus of this section; an earlier rural survey collecting 
data on income from 1990 will be briefly reviewed at the end of this section, despite concerns about comparability.

The three household surveys used here are the Household Living Conditions Survey_Enquête Intégrale sur les Conditions de Vie des ménages (EICV), in French-of 2000/1, 2005/6, and 2010/11. These were multi-purpose household surveys collecting among other things detailed data to enable the estimation of household consumption and income, based on short-period recall data for consumption. The first survey used the 1991 census as a sampling frame, but substantially complemented by a socioeconomic survey conducted in 1996/7 because of the substantial population changes since 1991; the second and third rounds used the 2002 population census for the sample frame, which was also used ex post to revise the weights from the first survey. Sample sizes were 6,420 in 2000/1, 6,900 in 2005/6, and 14,298 in 2010/11. The larger sample frame in the last case was designed to give data which would be representative at the new district level, following a reform in the structure of local government in 2006.

The three surveys were identical in terms of how they collected consumption data, and were used to estimate household consumption for each of the rounds. The measure of household consumption encompasses annualized estimates of purchases of food and non-food as well as consumption of home-produced food and non-food. In addition, consumption aggregates include spending on education, frequent health expenses, expenses on housing and utilities (electricity, water), the value of wages received in kind, the estimated value of services derived from durable goods, and the value of transfers received in kind from other households. An adult equivalence scale commonly used in Rwanda was used to express household consumption on a per equivalent adult basis, so taking account of differences in the size and composition of households. The detailed methodology is described in the appendix to the National Institute of Statistics of Rwanda's poverty report (GoR 2012a).

In analysing consumption poverty it is also important to take account of price differences between geographic locations, between months of the year, and between the periods of the different surveys. Very good price data was available in this case. The agriculture ministry had since 1999 been collecting frequent and consistent food price data on a large number of commodities across a large number of markets in Rwanda. This was used to estimate a food price index capturing all the spatial and temporal differences, using commodity weights from the survey data. A similar non-food index was constructed using the raw price data collected for the consumer price index in more urbanized areas and the two were combined into an overall cost-of-living index, which was used to deflate the consumption data computed from the survey. The index shows important differences by month, location, and between the survey rounds (GoR 2012a). 
Table 6.3. Consumption and consumption poverty by province

\begin{tabular}{|c|c|c|c|c|c|c|c|c|c|}
\hline & \multicolumn{3}{|c|}{$\begin{array}{l}\text { average consumption per } \\
\text { adult }\end{array}$} & \multicolumn{3}{|c|}{ poverty incidence } & \multicolumn{3}{|c|}{ poverty depth } \\
\hline & $2000 / 1$ & $2005 / 6$ & $2010 / 11$ & $2000 / 1$ & $2005 / 6$ & 2010/11 & $2000 / 1$ & $2005 / 6$ & $2010 / 11$ \\
\hline Kigali City & 253.2 & 289.5 & 324.8 & 0.227 & 0.208 & 0.168 & 0.366 & 0.346 & 0.284 \\
\hline Southern Province & 68.5 & 71.6 & 106.8 & 0.655 & 0.667 & 0.565 & 0.422 & 0.416 & 0.340 \\
\hline Western Province & 76.6 & 87.4 & 92.9 & 0.623 & 0.604 & 0.484 & 0.396 & 0.395 & 0.340 \\
\hline Northern Province & 73.4 & 76.1 & 110.0 & 0.642 & 0.605 & 0.428 & 0.431 & 0.400 & 0.340 \\
\hline Eastern Province & 71.4 & 89.9 & 104.5 & 0.593 & 0.521 & 0.426 & 0.415 & 0.357 & 0.302 \\
\hline RWANDA & 90.6 & 99.7 & 123.9 & 0.589 & 0.567 & 0.449 & 0.414 & 0.393 & 0.329 \\
\hline
\end{tabular}

Source: Government of Rwanda (2012a)

An absolute local currency poverty line was used in the analysis, of RwF118,000 per adult equivalent per year in 2010/11 prices (RwF64,000 January 2001 prices). This line had been set with reference to a minimum food consumption basket identified in 2000/1, judged to offer the number of calories required for a Rwandan who was likely to be involved in physically demanding work, along with an allowance for non-food consumption. An extreme poverty line was also set as the cost of buying the food consumption basket if nothing was spent on non-food at all, corresponding to RwF83,000 (RwF45,000 January 2001 prices). The consumption basket was an austere one, reflecting widespread levels of poverty at the time of the EICV1 survey.

The average level of consumption and estimates of poverty headcount and poverty depth (the average shortfall of the poor below the poverty line) are presented in Table 6.3, disaggregated across the five provinces of Rwanda. Average real household consumption per adult equivalent increased from RwF90,601 in 2000/1 to RwF99,749 in 2005/6, an annualized rate of increase of 1.9 per cent; between 2005/6 and 2010/11 it increased at an annualized rate of 4.5 per cent to reach RwF 123,891 in 2010/11. The data show a very sharp differential in the levels of consumption between Kigali and the other provinces. The four remaining provinces have much more similar average consumption levels. The provinces mostly show similar trends over time.

The poverty incidence figures show at the national level a modest reduction in poverty of 2.2 percentage points, between $2001 / 1$ and 2005/6. But there is then a sharp reduction of 11.8 percentage points between 2005/6 and 2010/ 11. A broadly similar pattern of change over time in poverty is seen in each province, except that in the Southern province poverty actually increased slightly between 2000/1 and 2005/6. There is a particularly sharp reduction in poverty in the Northern province between 2005/6 and 2010/11. All the province-level reductions in poverty between 2005/6 and 2010/11 are statistically significant at the 1 per cent level, though the changes between 2000/1 and 2005/6 are often not significant. Comparing levels of poverty between 
provinces it is very clear always that the levels of poverty are much lower in Kigali compared to the other four provinces. To a large extent this reflects urban-rural differences as the provinces outside Kigali are predominantly rural while Kigali province is predominantly urban. The depth of poverty shows similar patterns. It falls modestly between 2000/1 and 2005/6 and more between 2005/6 and 2010/11. The difference in the depth of poverty in Kigali and other provinces is much less than was the case for the incidence of poverty. In other words, those who are poor in Kigali are almost as poor on average as are the poor in other provinces.

It is equally important to look at inequality. At the national level, the Gini coefficient for Rwanda is high compared to neighbouring countries and internationally. It was 0.51 in $2000 / 1$ and increased modestly to 0.52 in $2005 / 6$, but then fell to 0.49 in 2010/11. Other inequality indices such as the ratio of the 90th to the 10th percentile show the same pattern of change. But the nature of the change of inequality is also highlighted visually through growth incidence curves for the 2000/1-2005/6 and 2005/6-2010/11 periods (Figures 6.2a and 6.2b). These show the growth in household consumption by percentile. What is clear is that for the first sub-period, consumption growth was higher at the top of the distribution than at the bottom, consistent with the increase in inequality. In the second sub-period though, growth was faster at the bottom of the distribution than at the top, again consistent with inequality falling. Thus in the first period, poverty reduction was modest because the growth in consumption was slower and it was associated with increasing inequality. In the second period, poverty fell much more, both because growth was faster and because inequality fell. It still remains the case in 2010/11 though that the level of inequality is high in Rwanda.

In summary, the pattern revealed by the survey data shows two very distinct periods. In the first period, over which GDP growth was also more modest (per capita GDP actually fell in 2001-2), consumption growth was also modest, inequality rose, and the incidence and depth of poverty only fell slightly, to an extent which was not statistically significant. In the second period, GDP growth was higher and consumption growth was much higher. Inequality also fell and there was a significant growth at the bottom of the distribution. Reflecting all this, both the incidence and depth of poverty fell significantly, indeed by a large magnitude.

As noted, the 2010/11 sample was large enough to permit indicators to be estimated at the district level. Figure 6.3 shows a map of Rwanda indicating district-level poverty estimates with darker colours representing higher poverty levels. It is very clear from this that poverty is lowest in Kigali (the lightshaded districts in the centre of the map) and in Musanze district in the north; it is also clear that it is in the districts in the south and west that poverty levels are highest. These are historically poorer areas of Rwanda, and they are often 
(a) Growth incidence curve $1999 / 2001$ to $2005 / 6$

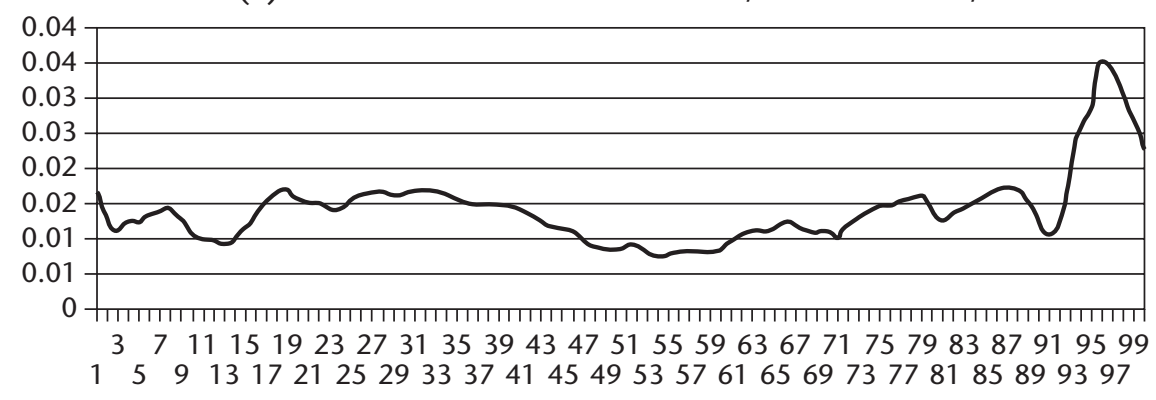

(b) Growth incidence curve $2005 / 6$ to $2010 / 11$

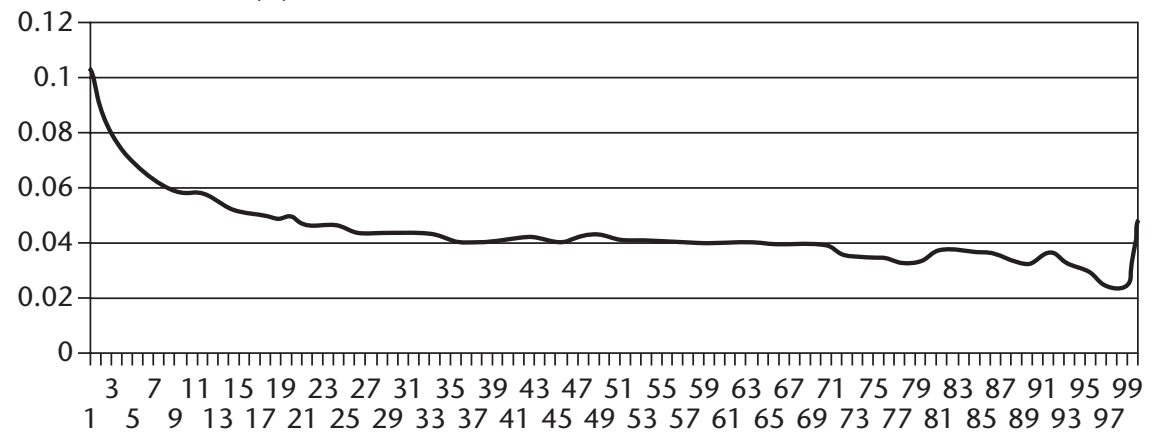

Figure 6.2. Growth incidence curves for Rwanda

Source: Government of Rwanda (2012a: 22)

also less urbanized and more remote. Figure 6.4 then shows changes in poverty between 2005/6 and 2010/11. Not all these changes are statistically significant but all in the lightest colour category are; what this map seems to suggest is much greater poverty reduction in districts located closer to borders with neighbouring countries (even some very poor ones in the south) and much less reduction or even increases in locations further from borders and often more remote. Cross-border trade may have been a factor contributing to this poverty reduction, but this needs further investigation.

An analysis looking at poverty in relation to a household's economic activities shows that those undertaking non-farm activity, either as wage work or self-employment, are much less poor than average; and that those reliant on farming activity are much poorer than average. The period between 2005/6 and 2010/11 showed an increase in the proportion of households in the survey reliant on non-farm activities, consistent with the overall poverty reduction over this period. In both years, among households reliant on farming it is those that are substantially reliant on farm wage work who are poorest 


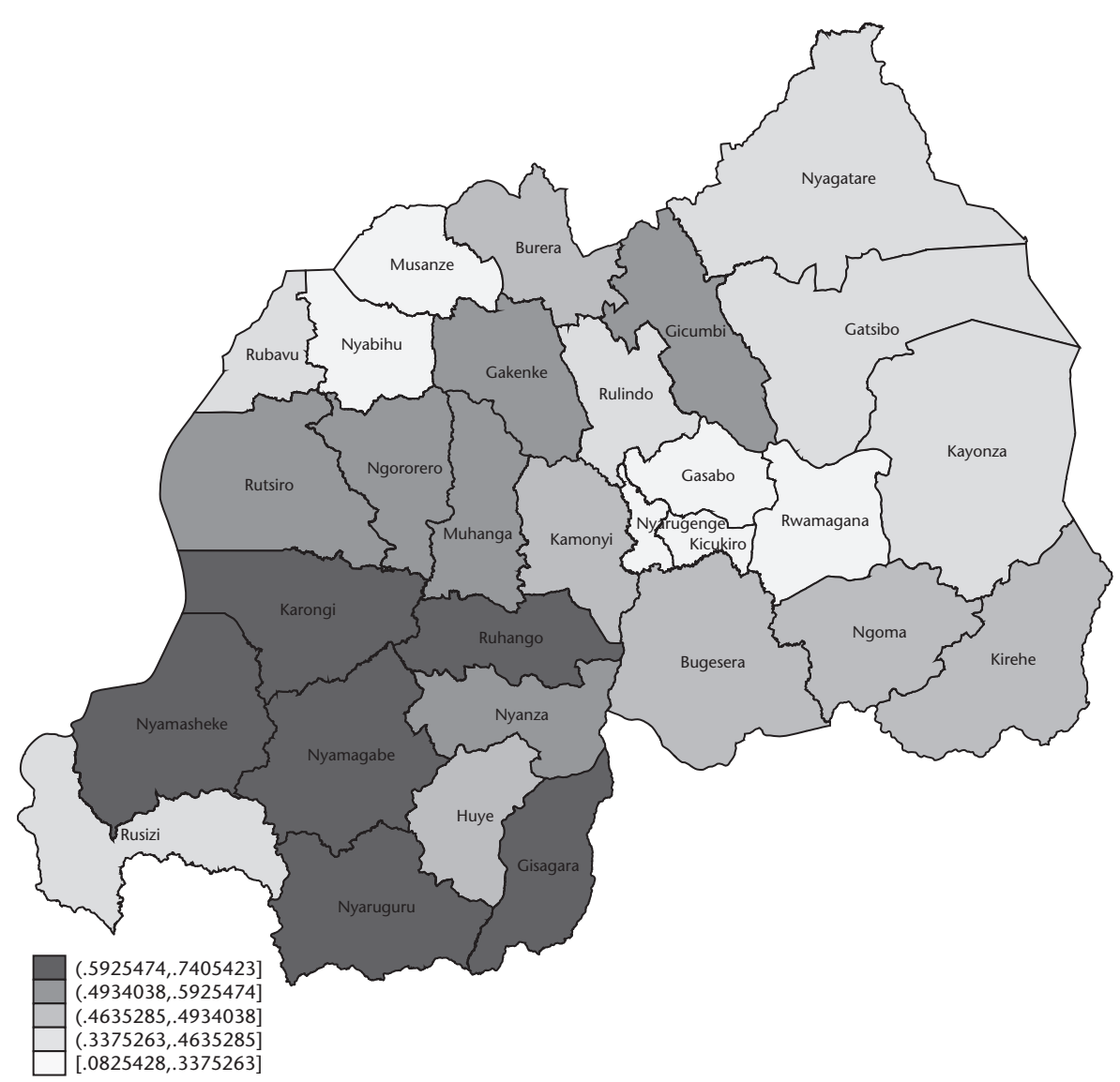

Figure 6.3. Pattern of poverty in Rwanda by district, 2010-11 Source: Government of Rwanda (2012a: 17)

of all. In 2005/6 and 2010/11 around 4 per cent of households get more than half their income from farm wage work, and 7 per cent and 8 per cent get at least 30 per cent of their household income from this source. This work is very badly paid and these households are among the poorest of all.

The consumption poverty results suggest that there has been substantial poverty reduction between 2005/6 and 2010/11; this is also the sub-period where the DHS indicators showed the fastest improvement. But these results need to be explained; and they need to be considered against local-level qualitative field research which gives a very different picture (Ansoms et al. 2010; Sommers 2012) as well as highly critical evaluations or assessments of a number of policy measures put in place by the government (e.g. villagization: Newbury 2011; land consolidation and crop intensification policies: Ansoms et al. 2010; Huggins 2009). 


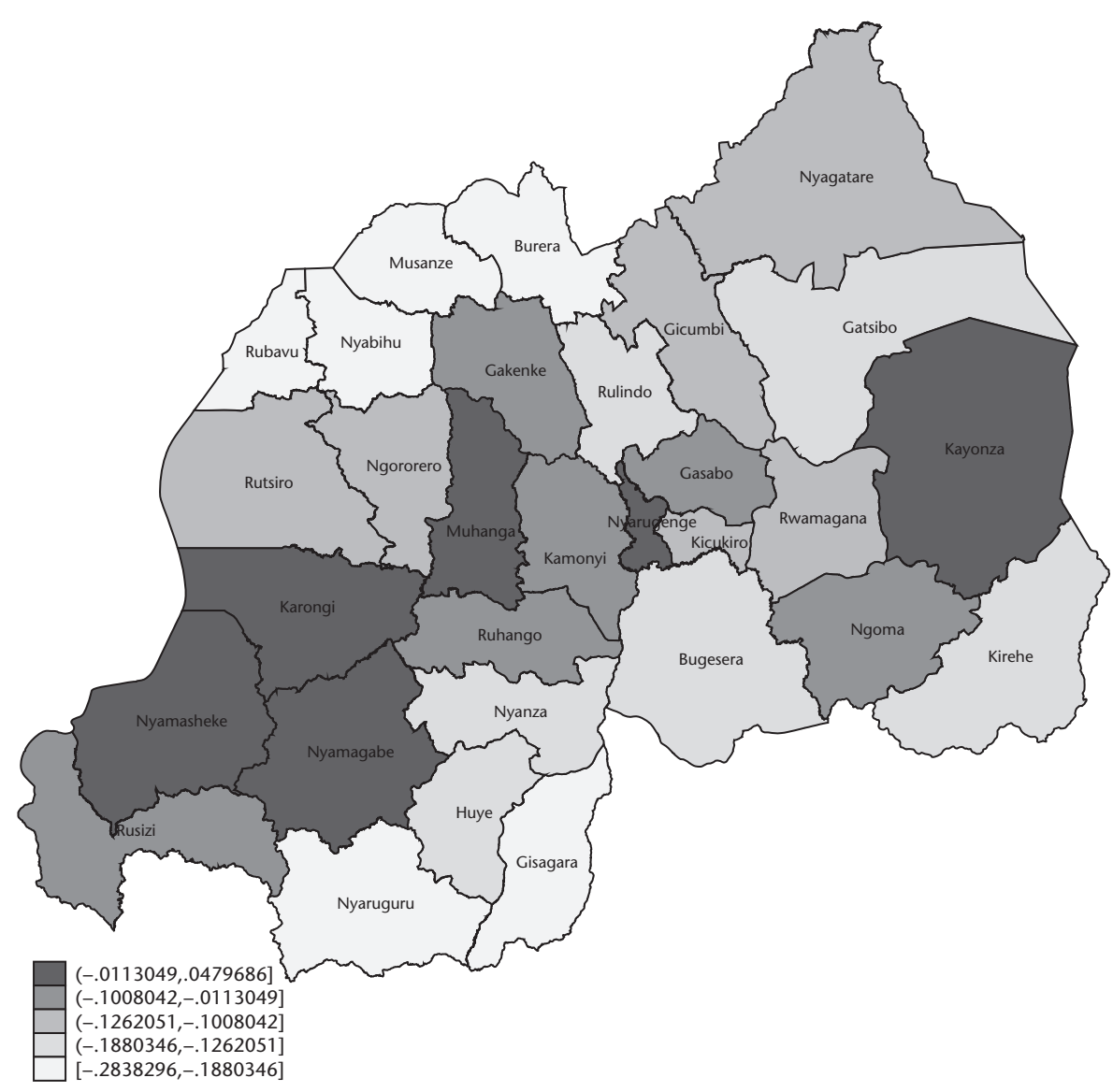

Figure 6.4. Changes in poverty in Rwanda between 2005/6 and 2010/11, by district Source: Authors' computation from the Rwanda EICV survey database

In seeking to explain the results, it is important first to bear in mind that poverty results reflect the economic conditions of the time period over which the data was collected, and can reflect exceptional circumstances in these years. To some extent, the relatively disappointing harvest in 2005/6 could partly explain both the lack of progress between 2000/1 and 2005/6 and the faster progress between $2005 / 6$ and 2010/11 as well as the attendant changes in inequality. The period covered by the second and third surveys was one over which agricultural production is reported to have increased substantially. The production of cereals, pulses, and roots was reported to have increased between 2005/6 and 2010/11 by 135 per cent, 21 per cent, and 95 per cent, respectively (World Bank 2013). The survey data also show that agricultural commercialization was higher in 2010/11 than 2005/6. Reyntjens (2012: 115) argues this point, stating that 'the consumption figures are a snapshot that 
might be determined by the output, strongly influenced by climate of the agricultural season preceding the survey'. Further potential support to this is given by the fact that total annual rainfall in 2010 was 50 per cent higher than in 2005 (1,200 mm compared to $800 \mathrm{~mm}$ ) (SSEE 2011).

Other factors though undoubtedly contributed to poverty reduction. One is the increased number of households able to undertake non-agricultural activities (though this may to some extent also be affected by the good agricultural performance), including an increase in available wage work opportunities (GoR 2012b). Smaller family size is another factor which will have had a positive impact on poverty reduction. Improved education and health outcomes, as evidenced in section 6.2 , are also likely to have contributed to improved economic outcomes for households.

But in terms of whether and which policies contributed to poverty reduction, the same point made above in relation to social sectors applies even more emphatically here. Given the lack of proper impact evaluations, nothing contained in this consumption poverty analysis can be decisively attributed to the different policies which have been put in place (e.g. agricultural and land policies; social protection; the Economic Development and Poverty Reduction Strategy itself).

Besides the absence of rigorous assessments, another issue is how to interpret 'improvements'. Some argue that they reflect the 'cosmetic upgrading of rural life' which 'hides the true extent of poverty and inequality' (Ansoms 2011: 247). This criticism is based on the coercion that accompanies many of the developmental measures, institutionalized in a system of fines-for not sending children to school, for walking bare-footed, or for consulting a traditional healer without authorization, among others. ${ }^{4}$ Ingelaere (2011: 73) argues that these fines may make rural dwellers 'look' less poor, even though they are likely to 'be and feel' as poor, or even poorer, than before. The issue of people's perceptions in relation to poverty will be revisited in section 6.4.

The comparisons on which this section focuses have been based on surveys conducted since 1994, and these are not properly comparable with earlier surveys. However, in terms of trying to make a pre-war comparison, a survey in 1990 collected quite detailed data on incomes of rural households, and McKay and Loveridge (2005) sought to compare this with income data collected from rural households in the 2000/1 EICV survey. Differences in methodology mean that considerable care is needed in making this comparison. The authors sought to define comparable concepts of income, and could also compare child anthropometric outcomes between the two surveys. Anthropometric outcomes for under-five children had improved slightly

\footnotetext{
${ }^{4}$ Following criticism of the fines, among others by donors, their actual implementation may have decreased in recent years (personal correspondence with Bert Ingelaere).
} 
between 1990 and 2000/1, despite a significant reduction in the average land size cultivated over the period; and average household income in 2000/1 had risen above its 1990 value (a result consistent with other data on agricultural production for this period). But there also appeared to be increasing inequality over this period (in line with the pattern observed in the DHS data); the richest 30 per cent of the sample in 2000/1 were significantly better off, but the remaining 70 per cent were in fact worse off in income terms, though not in terms of anthropometric outcomes. The latter paradox may be explained by changes in cultivation patterns over the period (e.g. more cultivation of cassava, less of cash crops) and reductions in sales of output over the period.

There may then have been progress also during 1990-2000. But the results for the post-2000 period are clearly more robust.

\subsection{Analysing Household Mobility Based on a Small Panel Dataset}

Panel data enables an analysis of economic mobility which cannot be done with the repeated cross-sectional data analysed above. The analysis in this section is based on a small panel data conducted in 2002 and 2008 in two locations in Rwanda, the former provinces of Gikongoro and Gitarama (now mainly in the Southern or Western provinces). It is interesting to note that much of this area was seen to have made less progress in consumption poverty in section 6.3. This survey was a follow-up of the same 1990 survey discussed in the previous section, but the analysis here focuses on the 2002 and 2008 rounds. The 2002 round was collected as part of a study for the Belgian Department for Development Cooperation (DGOS), and collected data from 258 households on themes including subsistence production, crop sales, livestock production, non-farm income, beer brewing, transfers, land ownership, household composition and schooling, war-related shocks, other adverse income shocks, and household consumption shortfalls. For a detailed description, see Verpoorten and Berlage (2007). The 2008 round used a similar design and was collected on a grant from the Rwandan government and LICOSCenter for Institutions and Economic Performance (University of Leuven). It sought to interview and collect similar information from all 258 households, but in the end interviewed 241 because the remaining households could not be found or could not be considered to be the same. Analysing attrition across the 2002 and 2008 rounds, we find little evidence that household characteristics drive attrition.

The data can be used to estimate household income as a welfare measure, and data are also available on land, livestock, and other assets. There is strong growth in average income between 2002 and 2008, with real income per adult 

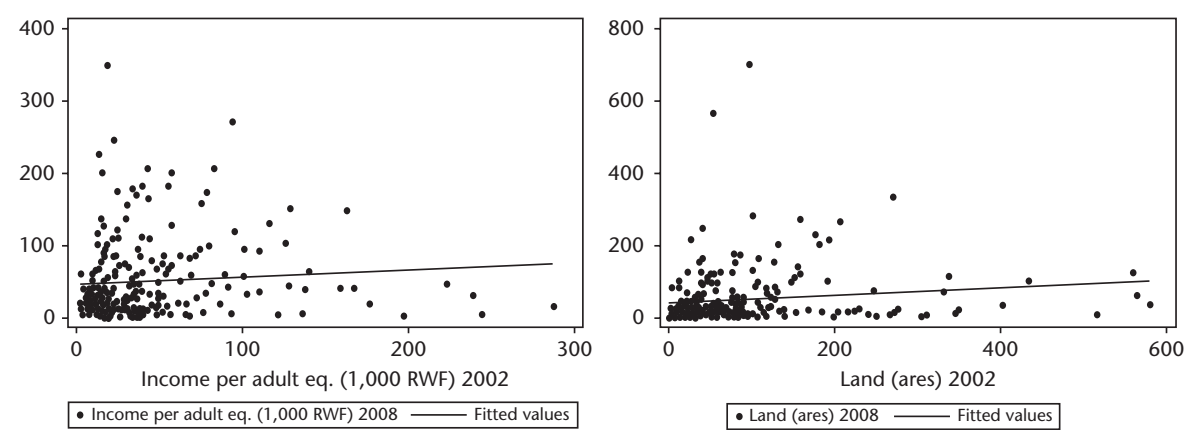

Figure 6.5. Scatterplots of 2008 values of income and land against their 2002 values Source: Computed from DGOS/Government of Rwanda/LICOS panel dataset; see text

equivalent (in prices of 2008) increasing from RwF54,614 in 2002 to RwF60,725 in 2008, a 11.2 per cent increase over the six-year period. This happened despite a sharp drop in average farm sizes from 0.89 ha in 2002 to 0.54 ha in 2008. Livestock ownership, expressed in TLU (tropical livestock units), was very similar in both years. There is a very small rise over the period in the contribution of non-farm wage employment (7.2 per cent to 7.6 per cent) and non-farm self-employment (9.4 per cent to 10.1 per cent). More important is the fact that agricultural productivity would seem to have increased, which may reflect the increased use of fertilizer as highlighted by the World Bank (2013), or simply better agricultural weather conditions. The data again highlight substantial inequality with the Gini coefficient of net income per adult equivalent being 0.56 and 0.55 in 2002 and 2008 respectively.

Of particular interest in a panel dataset is to look at mobility. Figure 6.5 presents scatterplots of income and land in 2008 compared to their 2002 values. The land scatterplot shows reductions in the large majority of cases, including some very large reductions. The income plot shows much greater heterogeneity, with many increases but also a large number of reductions. A regression analysis, based on a production function approach, of the level of income found that there were large, positive, and significant returns to land and labour. In addition, income in 2008 depends positively and significantly on income in 2002 and on changes in labour and land between 2002 and 2008 (Verpoorten 2014).

The 2008 survey also classified households into six widely used social categories that emerged from the 2001 nationwide participatory poverty assessment (PPA, ubudehe). ${ }^{5}$ The categories range from 'the abject poor'

\footnotetext{
${ }^{5}$ The PPA was implemented nationwide in a sample of administrative sectors. In each sector, facilitators consulted with a large number of community members (about 300), aiming to identify different social categories as seen by Rwandans themselves. The characteristics of these groupings
} 
Table 6.4. Mobility matrix of self-reported social categories

\begin{tabular}{|c|c|c|c|c|c|c|c|}
\hline & & \multicolumn{6}{|c|}{ Categories in 2008} \\
\hline & & $\begin{array}{l}\text { umutindi } \\
\text { nyakujya }\end{array}$ & umutindi & umukene & $\begin{array}{l}\text { umukene } \\
\text { wifashije }\end{array}$ & umukungu & umukire \\
\hline \multirow{12}{*}{$\begin{array}{c}\text { Categories } \\
\text { in } 2002\end{array}$} & umutindi nyakujya & 6 & 0 & 1 & 0 & 0 & 0 \\
\hline & & 85.7 & 0.0 & 14.3 & 0.0 & 0.0 & 0.0 \\
\hline & umutindi & 0 & 19 & 8 & 4 & 0 & 0 \\
\hline & & 0.0 & 61.3 & 25.8 & 12.9 & 0.0 & 0.0 \\
\hline & umukene & 1 & 4 & 70 & 27 & 0 & 0 \\
\hline & & 1.0 & 3.9 & 68.6 & 26.5 & 0.0 & 0.0 \\
\hline & umukene wifashije & 0 & 4 & 8 & 66 & 2 & 0 \\
\hline & & 0.0 & 5.0 & 10.0 & 82.5 & 2.5 & 0.0 \\
\hline & umukungu & 0 & 0 & 1 & 5 & 11 & 0 \\
\hline & & 0.0 & 0.0 & 5.9 & 29.4 & 64.7 & 0.0 \\
\hline & umukire & 0 & 0 & 0 & 0 & 1 & 1 \\
\hline & & 0.0 & 0.0 & 0.0 & 0.0 & 50.0 & 50.0 \\
\hline
\end{tabular}

Source: Small DGOS/Government of Rwanda/LICOS panel dataset; see text

(umutindi nyakujya) to 'the money rich' (umukire). The intermediate categories are 'the very poor', 'the poor', 'the resourceful poor', and 'the food rich' (umutindi, umukene, umukene wifashije, umukungu). These categories are described in more detail in the Appendix to this chapter. The 2008 survey also asked households to report their ubudehe status in 2002. The social categories reported by respondents correlate quite strongly with the income, land, and livestock data available from the survey.

This then gives an alternative, self-reported measure of mobility to the income and land-based measures above, and a mobility matrix is reported in Table 6.4. In this matrix, nearly 70 per cent of households remain in the same category between these two years, but where there is mobility it is mostly upward, especially people moving out of categories 2 and 3 to typically the next highest group. Howe and McKay (2007) in an earlier analysis interpreted the first three categories as being likely to include a substantially higher number of chronically poor households, but even some of these appear to have been able to move up into a higher group. In 2002, we find about 13 per cent in the second category and 43 per cent in the third category, compared to 11 per cent and 37 per cent in 2008 . While the lowest three categories make up almost 59 per cent of the sample in 2002, their share stands at 51 per cent in 2008 , thus marking a decline in poverty.

The survey also asked respondents directly about the reasons for upward and downward mobility in terms of these categories (Figure 6.6). Once again, production factors figure large here, with a good harvest, better and more land, 


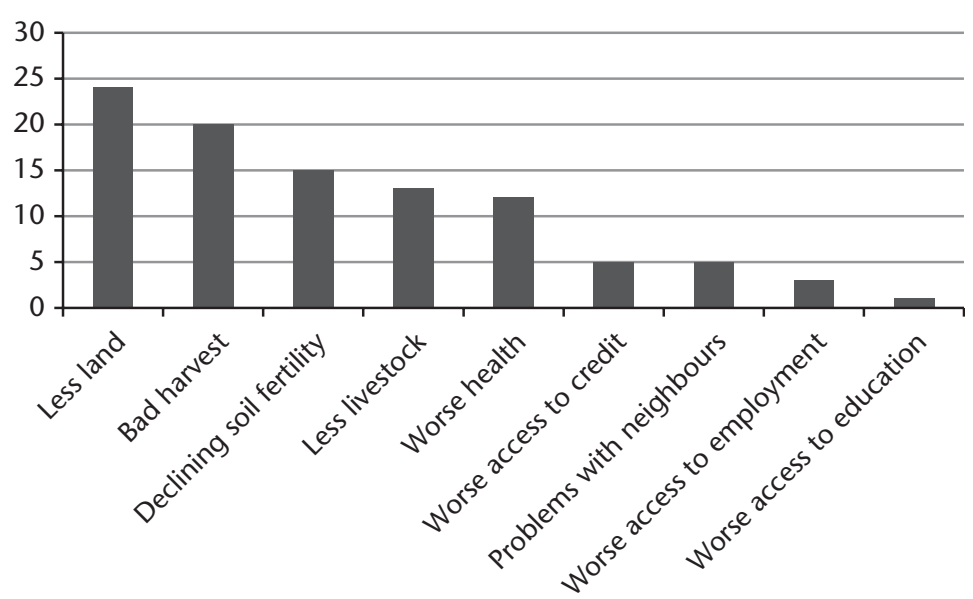

Figure 6.6. Self-reported reasons for social mobility between $u b u d e h e$ categories Source: Computed from DGOS/Government of Rwanda/LICOS panel dataset; see text

and more livestock being reported as the most important factors behind upward mobility; and the opposite factors being the main reasons behind downward mobility.

Finally and importantly the 2008 round of the panel data set also asked household heads the twelfth question of the GHQ-12, the General Health Questionnaire, developed by Goldberg and Blackwell (1970): 'Have you recently been feeling reasonably happy all things considered?' (Goldberg and Blackwell 1970), with the following response categories: 'strongly agree', 'agree', 'disagree', and 'strongly disagree'. About 10 per cent of household heads strongly agree, 57 per cent agree, 21 per cent disagree, and 12 per cent strongly disagree (see Table 6.5). These responses suggest that close to one out of three household heads felt unhappy. Looking at the distribution of income, assets, and mobility across the answer categories, happiness is weakly positively correlated with income, but strongly correlated with relative income mobility (both measured and self-reported): those who moved more upward feel more happy. Strikingly, however, even the unhappy experienced a positive absolute change in average income ( $+21,000$ vs $+85,000$ for the happy), suggesting that it is not levels nor absolute changes in income that matter, but

${ }^{6}$ The GHQ has been translated into many languages. It was cross-culturally validated as part of a World Health Organization project on mental illness conducted in both developing and developed countries (Goldberg et al. 1997). During the preparation phase of the 2008 round of the panel data, we let the GHQ-12 be translated from English to Kinyarwanda and then back from Kinyarwanda to English by two different translators (double-blinded). We compared the retranslated English version with the original one to spot problems, which were then discussed in detail with both translators until a consensus on an accurate translation was reached. We acknowledge input from Pieter Serneels in this process. 
Table 6.5. Happiness, and mean income, assets, and income change by happiness

\begin{tabular}{|c|c|c|c|c|c|c|c|c|c|}
\hline \multicolumn{7}{|c|}{$\begin{array}{l}\text { Have you recently been feeling reasonably happy all things } \\
\text { considered? }\end{array}$} & \multirow[b]{2}{*}{$\begin{array}{l}\text { Female } \\
\text { head } \\
08\end{array}$} & \multirow[b]{2}{*}{$\begin{array}{l}\text { Income } \\
\text { change } \\
02-08\end{array}$} & \multirow[b]{2}{*}{$\begin{array}{l}\text { Self-reported } \\
\text { mobility: } \\
\text { 'better' }\end{array}$} \\
\hline & $\mathrm{Nr}$ & $\%$ & $\begin{array}{l}\text { Cum } \\
\%\end{array}$ & $\begin{array}{l}\text { Income/ } \\
\text { ae } 08\end{array}$ & $\begin{array}{l}\text { Land } \\
08 \\
\text { (ares) }\end{array}$ & $\begin{array}{l}\text { Livestock } \\
08 \text { (TLU) }\end{array}$ & & & \\
\hline strongly disagree & 29 & 11.6 & 11.6 & 77,897 & 33.33 & 0.93 & 0.59 & 15,146 & 0.21 \\
\hline disagree & 52 & 20.8 & 32.4 & 47,820 & 40.45 & 0.86 & 0.51 & 26,078 & 0.24 \\
\hline agree & 143 & 57.2 & 89.6 & 61,961 & 62.92 & 1.24 & 0.46 & 69,011 & 0.31 \\
\hline strongly agree & 26 & 10.4 & 100 & 70,134 & 81.47 & 1.39 & 0.19 & 183,623 & 0.42 \\
\hline
\end{tabular}

Source: Small DGOS/Government of Rwanda/LICOS panel dataset; see text

relative changes. Happiness also strongly correlated with land ownership. Those who report being happy have about 75 per cent more land than 'the unhappy' (0.65 ha versus $0.38 \mathrm{ha})$. The average decline in landholdings was also significantly larger among the unhappy than among the happy (0.53 ha vs 0.25 ha, not reported).

The importance of relative wealth for subjective well-being has also been underlined in many other studies including Luttmer (2005), Kingdon and Knight (2007), and Fafchamps and Shilpi (2008), among others. The importance of relative landholdings aligns well with the findings of Van Landeghem et al. (2011) who study the subjective well-being (SWB) of farm households in the context of land reform in Moldova.

The fact that happiness is not strongly correlated with the level of material well-being is an important finding, and may help explain something of the difference between the indicators reported in the survey-based results and the results of the qualitative fieldwork. Progress in terms of levels of monetary and non-monetary indicators does not necessarily mean that people feel better off, certainly when others are also making progress, at a faster rate.

\subsection{Conclusions}

In many respects Rwanda has made very impressive progress in the period since 1994, showing sustained growth at fast rates, even accelerating in recent years. This represents a substantial change from the pre-1994 situation of no, or at best, low and unsustained growth. This chapter has examined the changes in living conditions which have taken place alongside this growth. It shows substantial progress in both non-monetary indicators of well-being and consumption poverty, with faster progress since around 2005 in each case. The 2002-8 panel survey also suggests that people have become better off in income terms and in terms of their own self-assessment (in terms of the 
ubudehe categories). There is therefore strong evidence of improving living conditions alongside the economic growth.

In the case of consumption or income, given the typical fluctuations in such variables over time, the results of the comparisons between two or more years can be quite sensitive to the precise timing of the surveys. Hence the comparisons of these variables may or may not indicate longer-term trends. But many non-monetary measures vary much less over time, rather evolving more gradually and consistently. The non-monetary measures considered here mostly show improvement which is just as impressive as that in consumption poverty. Mortality rates have fallen consistently since 2000 , access to health care has much improved, education levels have increased, asset holdings and housing conditions have improved, and these improvements have happened for the poor as much as for the non-poor. While complete explanations of these changes are currently lacking, these changes are beyond mere post-war catch-up.

Because of the various channels of multi-way causation between income, health, education, and other outcomes, it is not surprising that the improvements in human development outcomes as inferred from the DHS data are in line with the poverty and inequality trends that emerge from data on consumption expenditures. But how can this evidence of pro-poor growth be reconciled with the much more pessimistic findings of mostly qualitative fieldwork at the local level?

The analysis of dynamic and subjective measures of household well-being based on the small panel dataset may provide some clues. Respondents' happiness levels turned out to be very weakly related to income levels, but correlated much more strongly with relative income changes and landholdings. These findings suggest that subjective measures of well-being do not necessarily align well with objective measures of well-being; and that the mismatch may be considerable in Rwanda as a result of rapid and profound economic and social transformations. This creates uncertainty; it leads to winners and losers (in relative terms); and it affects traditional land- and subsistence-based livelihoods. In particular, peasants have often had great difficulty in responding to many of the policies introduced-for example, in relation to land consolidation and monocropping-and the speed of the implementation makes this more difficult.

It is very difficult also to say to what extent the improvements have been due to the many different government policy interventions which have been put in place over the period. Many of these interventions are quite recent; but more importantly they mostly have not been properly evaluated. Thus, for example, it is not yet possible to know whether changes in land and agricultural policy can account for the significantly increased production levels in the sector. The requirement for increased upward accountability from the 
local to the central government level via performance contracts or imihigo (Ingelaere 2011) might have played a role in improvements in health and education (or even economic growth), but this has not been evaluated. The massive increase in health care spending (increasing by a factor of 2.5 between 2004 and 2010), coupled with the introduction of performance-based financing, is nonetheless likely to be an important factor behind the improved health outcomes (Basinga et al. 2010). A similar comment applies in the education sector. Aid would seem to have played an important role here, as it probably has in stimulating growth more widely. But there is currently insufficient information to assess the relative role of public policy measures, greater effectiveness of policy implementation, aid, and other factors in accounting for the observed outcomes in terms of living conditions.

Although the technically capable government is well underway to reach several of the Millennium Development Goals, Rwanda's path to development remains controversial, because of the sharp contrast between the impressive economic progress and the standstill in 'voice and accountability', one of the six Kaufmann et al. (2010) governance indicators. These allegations cast a shadow over the regime's economic successes and leave the scholar and donor community deeply divided on how to approach Rwanda, and what to expect-can the lack of progress on 'voice and accountability' pose a risk to the sustainability of the achievements to date? If anything, Rwanda's history should make observers especially attentive to evolutions in social, political, and economic exclusion (Ingelaere and Verpoorten 2014).

Another point of concern highlighted in this analysis is the continued high level of inequality in Rwanda, even if this has fallen recently and has become an important government priority. Inequality in Rwanda is higher than in most or all other countries in Eastern Africa and this must be a concern for cohesion and sustainability, exacerbated by the above concerns about voice and accountability. The extent of the gap between Kigali and the rest of the country remains an important dimension of this, though there are also large levels of inequality within provinces. 
Growth, Poverty Reduction, and Inequality in Rwanda

\section{Appendix: Rwandan Social Categories}

\begin{tabular}{|c|c|}
\hline Social category & Characteristics \\
\hline $\begin{array}{l}\text { Umutindi nyakujya (those in } \\
\text { abject poverty) }\end{array}$ & $\begin{array}{l}\text { Those who need to beg to survive. They have no land or livestock } \\
\text { and lack shelter, adequate clothing, and food. They fall sick often } \\
\text { and have no access to medical care. Their children are } \\
\text { malnourished and they cannot afford to send them to school. }\end{array}$ \\
\hline Umutindi (the very poor) & $\begin{array}{l}\text { The main difference between the umutindi and the umutindi } \\
\text { nyakujya is that this group is physically capable of working on } \\
\text { land owned by others, although they themselves have either no } \\
\text { land or very small landholdings, and no livestock. }\end{array}$ \\
\hline Umukene (the poor) & $\begin{array}{l}\text { These households have some land and housing. They live on their } \\
\text { own labour and produce; though they have no savings, they can } \\
\text { eat, even if the food is not very nutritious. However, they do not } \\
\text { have a surplus to sell in the market, their children do not always } \\
\text { go to school, and they often have no access to health care }\end{array}$ \\
\hline $\begin{array}{l}\text { Umukene wifashije (the } \\
\text { resourceful poor) }\end{array}$ & $\begin{array}{l}\text { This group shares many of the characteristics of the umukene, but in } \\
\text { addition they have small ruminants and their children go to } \\
\text { primary school. }\end{array}$ \\
\hline Umukungu (the food rich) & $\begin{array}{l}\text { This group has larger landholdings with fertile soil and enough to } \\
\text { eat. They have livestock, often have paid jobs, and can access } \\
\text { health care. }\end{array}$ \\
\hline Umukire (the money rich) & $\begin{array}{l}\text { This group has land and livestock, and often has salaried jobs. } \\
\text { They have good housing, often own a vehicle, have enough money } \\
\text { to lend, and get credit from banks. Many migrate to urban } \\
\text { centres. }\end{array}$ \\
\hline
\end{tabular}

Source: Government of Rwanda (2002)

\section{References}

Ansoms, A. (2011). 'Rwanda's Post-Genocide Economic Reconstruction: The Mismatch between Elite Ambitions and Rural Realities', in S. Straus and L. Waldorf (eds), Remaking Rwanda: State Building and Human Rights after Mass Violence. Madison, WI: University of Wisconsin Press, 240-51.

Ansoms, A., A. Verdoodt, and E. Van Ranst (2010). 'A Green Revolution for Rural Rwanda: Reconciling Production Growth with Small-Scale Risk Management'. A paper prepared for the Ten Years of War Against Poverty conference, 8-10 September, Manchester, UK, <http://www.chronicpoverty.org/uploads/publication_files/ ansoms_et_al_rwanda.pdf>.

Ayalew, A. D., K. Deininger, and M. Goldstein (2011). 'Environmental and Gender Impacts of Land Tenure Regularization in Africa: Pilot Evidence from Rwanda', World Bank Policy Research Working Paper No. 5765. Washington, DC: World Bank.

Basinga, P., P. J. Gertler, A. Binagwaho, A. L. B. Soucat, J. R. Sturdy, and C. M. J. Vermeesch (2010). 'Paying Primary Healthcare Centers for Performance in Rwanda', World Bank Policy Research Working Paper No. 5190. Washington, DC: World Bank. 


\section{Rapid Growth and Rapid Poverty Reduction}

Booth, D. and F. Golooba-Mutebi (2012). 'Developmental Patrimonialism? The Case of Rwanda', African Affairs, 111(444): 379-403.

DHS (Demographic and Health Surveys) (1992, 2000, 2005, 2007, 2010). MEASURE DHS project, obtained from ICF Macro, <http://www.measuredhs.com>.

Fafchamps, M. and F. Shilpi (2008). 'Subjective Welfare, Isolation, and Relative Consumption', Journal of Development Economics, 86: 43-60.

Filmer, D. and L. Pritchett (2001). 'Estimating Wealth Effects without Expenditure Data-or Tears: An Application to Educational Enrollments in the States of India', Demography, 38: 115-32.

Goldberg, D. P. and B. Blackwell (1970). 'Psychiatric Illness in General Practice: A Detailed Study Using a New Method of Case Identification', British Medical Journal, 1: 439-43.

Goldberg, D. P., R. Gater, N. Sartorious, T. Ustun, M. Piccinelli, O. Gueje, and C. Rutter (1997). 'The Validity of Two Versions of the GHQ in the WHO Study of Mental Illness in General Healthcare', Psychological Medicine, 27(1): 191-7.

GoR (Government of Rwanda) (2002). 'The Government of Rwanda Poverty Reduction Strategy Paper', National Poverty Reduction Programme, Ministry of Finance and Economic Planning, June. Available at <http://siteresources.worldbank.org/ INTPRS1/Resources/Country-Papers-and-JSAs/Rwanda_PRSP.pdf $>$.

GoR (Government of Rwanda) (2012a). 'The Evolution of Poverty in Rwanda from 2000 to 2011: Results from the Household Surveys (EICV)', National Institute of Statistics of Rwanda.

GoR (Government of Rwanda) (2012b). 'EICV 3 Thematic Report: Economic Activity', National Institute of Statistics of Rwanda.

Guariso, A., C. J. Ngabitsinze, and M. Verpoorten (2012). 'The Rwandan Coffee Sector: Out of the Ordinary', in F. Reyntjens, S. Vandeginste, and M. Verpoorten (eds), L'Afrique des grands lacs: Annuaire 2011-2012. Paris, L'Harmattan, 397-426.

Guariso, A. and M. Verpoorten (2013). 'Armed Conflict and Schooling in Rwanda: Digging Deeper', LICOS Discussion Papers 343, LICOS-Centre for Institutions and Economic Performance, KULeuven.

Howe, G. and A. McKay (2007). 'Combining Quantitative and Qualitative Methods in Assessing Chronic Poverty: The Case of Rwanda', World Development, 35(2): 197-211.

Huggins, C. (2009). 'Agriculture Policies and Local Grievances in Rural Rwanda', Peace Review, 21(3): 296-303.

Ingelaere, B. (2011). 'The Ruler's Drum and the People's Shout: Accountability and Representation on Rwanda's Hills', in S. Straus and L. Waldorf (eds), Remaking Rwanda: State Building and Human Rights after Mass Violence. Madison, WI: University of Wisconsin Press, 67-78.

Ingelaere, B. and M. Verpoorten (2014). 'Rwanda: Could State-Led Mass Killings Ever Happen Again?', African Arguments, 2 June. Available at <http://africanarguments. org/2014/06/02/rwanda-could-state-led-mass-killings-ever-happen-again-by-bertingelaere-marijke-verpoorten/>.

Kabano, I. H., A. Broekhuis, and P. Hooimeijer (2013). 'Fertility Decline in Rwanda: Is Gender Preference in the Way?', International Journal of Population Research, vol. 2013, Article ID 787149, 9 pp. 
Kalk, A. (2008). 'Rwanda's Health System: Some Concerns', The Lancet, 372: 1729.

Kalk, A., F. A. Paul, and E. Grabosch (2010). 'Payment for Performance in Rwanda: Does it Pay Off?', Tropical Medicine and International Health, 15(2): 182-90.

Kaufmann, D., A. Kraay, and M. Mastruzzi (2010). 'The Worldwide Governance Indicators: Methodology and Analytical Issues', World Bank Policy Research Working Paper 5430. Washington, DC: World Bank.

Kingdon, G. G. and J. Knight (2007). 'Community, Comparisons and Subjective Well-being in a Divided Society', Journal of Economic Behavior \& Organization, 64: 69-90.

Luttmer, E. F. P. (2005). 'Neighbours as Negatives: Relative Earnings and Well-being', Quarterly Journal of Economics, 120(3): 963-1002.

McKay, A. and S. Loveridge (2005). 'Exploring the Paradox of Rwandan Agricultural Household Income and Nutritional Outcomes in 1990 and 2000', Michigan State University Staff Paper 2005-06, March.

Muhoza, D. N., P. C. Rutayisire, and A. Umubyeyi (2013). 'Measuring the Success of Family Planning Initiatives in Rwanda: A Multivariate Decomposition Analysis', DHS Working Paper No. 49.

Newbury, C. (2011). 'High Modernism at the Ground Level: The Imidugudu Policy in Rwanda', in S. Straus and L. Waldorf (eds), Remaking Rwanda: State Building and Human Rights after Mass Violence. Madison, WI: University of Wisconsin Press, 223-39.

Nkurunziza, J., A. Broekhuis, and P. Hooimeijer (2012). 'Free Education in Rwanda: Just One Step towards Reducing Gender and Sibling Inequalities', Education Research International, 2012, Article ID 396019, 11 pp.

Reyntjens, F. (2012). 'Elite Ambitions: Engineering a New Rwanda and New Rwandans', in C. Panella (ed.), Lives in Motion, Indeed: Interdisciplinary Perspectives on Social Change in Honour of Danielle de Lame (Studies in Social Sciences and Humanities 174). Tervuren, Belgium: Royal Museum for Central Africa Publishers, 93-120.

Saksena, P., A. F. Antunes, K. Xu, L. Musango, and G. Carrin (2011). 'Mutual Health Insurance in Rwanda: Evidence on Access to Care and Financial Risk Protection', Health Policy, 99(3): 203-9.

SSEE (Smith School of Enterprise and Environment) (2011). 'Rwanda's Climate: Observations and Projections', July, University of Oxford.

Sommers, M. (2012). Stuck: Rwandan Youth and the Struggle for Adulthood. Athens, GA: University of Georgia Press.

Van Landeghem, B., J. Swinnen, and L. Vranken (2011). 'Land and Happiness: Land Distribution and Subjective Well-being in Moldova', Eastern European Economics, 51 (1): 61-85

Verpoorten, M. (2012). 'Leave None to Claim the Land: A Malthusian Catastrophe in Rwanda?', Journal of Peace Research, 49(4): 547-63.

Verpoorten, M. (2014). 'Growth, Poverty and Inequality in Rwanda: A Broad Perspective', WIDER Working Paper 2014/138. Helsinki: UNU-WIDER.

Verpoorten, M. and L. Berlage (2007). 'Economic Mobility in Rural Rwanda: A Study of the Effects of War and Genocide at the Household Level', Journal of African Economies, 16: 349-92. 


\section{Rapid Growth and Rapid Poverty Reduction}

Westoff, C. (2012). 'The Recent Fertility Transition in Rwanda', Population and Development Review, 38 (Supplement): 169-78.

World Bank (2013). 'Rwanda Economic Update: Maintaining Momentum, with a Special Focus on Rwanda's Pathway out of Poverty', Working Paper No. 78229. Washington, DC: World Bank.

World Bank (2014). 'World Development Indicators'. Washington, DC: World Bank. 